\title{
Pengaruh Formalin dan Periode Simpan terhadap Viabilitas dan Pertumbuhan Awal Benih Kelengkeng (Dimocarpus longan)
}

\section{Effect of Formaldehyde and Storage Period on Viability and Early Growth of Longan Seeds (Dimocarpus longan)}

\author{
Sifron Akbar ${ }^{1 *}$, Dwi Retno Lukiwati ${ }^{2}$, Florentina Kusmiyati ${ }^{2}$ \\ ${ }^{1}$ Program Studi Agroteknologi, Departemen Pertanian, Fakultas Peternakan dan Pertanian \\ Universitas Diponegoro \\ ${ }^{2}$ Departemen Pertanian, Fakultas Peternakan dan Pertanian, Universitas Diponegoro \\ *Email : akbar.sifron@gmail.com
}

\begin{abstract}
ABSTRAK
Penelitian ini bertujuan untuk mengkaji pengaruh penggunaan formalin dan periode simpan terhadap viabilitas dan pertumbuhan awal benih kelengkeng. Rancangan percobaan berdasarkan rancangan acak lengkap faktorial dengan 4 ulangan. Faktor pertama adalah formalin $(0 \%, 0,5 \%, 1 \%$ dan 2\%). Faktor kedua adalah periode simpan dengan 3 taraf (tanpa penyimpanan, 15 dan 30 hari). Parameter yang diamati adalah daya kecambah, kecepatan berkecambah, Jumlah daun dan tinggi bibit kelengkeng. Data yang diperoleh dianalisis ragam taraf 5\% dan apabila berpengaruh nyata $(\mathrm{p}<0,05)$, dilanjutkan dengan uji jarak berganda Duncan (DMRT) pada taraf 5\%. Hasil penelitian menunjukkan bahwa meningkatnya kadar formalin, nyata menurunkan daya kecambah dan kecepatan berkecambah, sedangkan kadar formalin $0,5 \%$ dengan 30 hari periode simpan optimal meningkatkan jumlah daun dan tinggi tanaman.
\end{abstract}

Kata kunci : kelengkeng, formalin, periode simpan, viabilitas, pertumbuhan awal

\section{ABSTRACT}

The aim of this research was to observe of formaldehyde and storage periode on viability and early growth of longan seed. The research used Factorial Completely Randomized Design $4 \times 3$ and 4 time replication. The first factor was formaldehyde $(0 \%, 0,5 \%, 1 \%$ dan $2 \%)$. The second factor is storage periode ( 0 day, 15 days and 30 days). Parameter observed were germination capacity (percentage), germination rate, number of leaf dan height of longan seed. Data were analysis of variabel at level of $5 \%$ and if it had significant effect $(\mathrm{p}<0,05)$, further test with Duncan's Multiple Range Test (DMRT) at level of 5\%. The result showed that increase in formaldehyde level, significant decrease germination capacity and germination rate. Meanwhile combination of $0,5 \%$ formaldehyde and 30 days storage periode significant increase number of leaf and seed height.

Keywords : longan, formaldehyde, storage periode, viability, early growth

\section{PENDAHULUAN}

Kelengkeng (Dimocarpus longan) merupakan salah satu buah yang memiliki nilai ekonomi tinggi di Indonesia. Kelengkeng memiliki bentuk daun meruncing dan berwarna hijau gelap. Batangnya bercabang dan arah cabang mendatar dan rapat. Bunga kelengkeng mempunyai tiga tipe yaitu bunga jantan, betina dan hermaprodit. Semua varietas lengkeng mempunyai bunga jantan dan betina, tetapi belum tentu memiliki bunga hermaprodit (Balitjestro, 2014). Buah kelengkeng merupakan buah tropis yang mengandung zat gizi, antara lain sukrosa, glukosa, protein dan vitamin. Produksi kelengkeng di Indonesia termasuk dalam kategori minor, sehingga belum tercantum pada data produksi badan pusat satistik (BPS) (Rukmana, 2005). Produksi kelengkeng Indonesia perlu ditingkatkan salah satunya dengan upaya penyebaran kelengkeng ke berbagai provinsi, namun permintaan bibit batang bawah dari luar provinsi tidak mampu dipenuhi karena kesulitan menjaga bibit kelengkeng tidak rusak selama pengiriman. Solusi yang dapat dilakukan adalah 
dengan upaya penyimpanan dan pengiriman benih kelengkeng. Penyimpanan yang tepat akan meningkatkan lama penyimpanan benih, sehingga dapat diperoleh benih yang bermutu sampai waktu benih akan ditanam. Benih kelengkeng merupakan benih rekalsitran yang tidak dapat disimpan dalam waktu lama karena harus memiliki kadar air diatas $20 \%$ untuk mempertahankan viabilitasnya (Yudono, 2012). Kadar air yang tinggi akan membuat benih mudah terserang cendawan terutama saat penyimpanan. Serangan cendawan akan menyebabkan penurunan mutu benih yang mengakibatkan kerusakan antara lain kerusakan fisik, perubahan warna dan benih menjadi busuk sebelum atau sesudah berkecambah (Sutopo, 2012). Serangan cendawan pada benih kelengkeng,dapat dicegah dengan berbagai cara, salah satunya adalah dengan menggunakan desinfektan. Salah satu jenis desinfektan yang dapat digunakan adalah formalin. Formalin dengan kadar 2-8\% dapat digunakan sebagai germisida (BPOM, 2008). Formalin 0,5\% selama 2 jam pada benih Orobanche ramose mampu menghilangkan bakteri dan jamur, namun persentase perkecambahan benih Orobanche ramose menurun menjadi 70\% (González-Verdejo et al., 2005). Formalin dengan berbagai konsentrasi perlu diteliti untuk mengetahui konsentrasi mana yang paling optimal dalam memperpanjang umur simpan benih kelengkeng dan dampaknya terhadap viabilitas benih serta pertumbuhan awal kelengkeng.

\section{METODE PENELITIAN}

Penelitian ini telah dilaksanakan selama empat bulan yaitu pada bulan Juli sampai bulan Oktober 2017 di Greenhouse dan Laboratorium Fisiologi dan Pemuliaan Tanaman, Fakultas Peternakan dan Pertanian, Universitas Diponegoro, Semarang. Bahan yang digunakan dalam penelitian ini meliputi: benih kelengkeng itoh, arang sekam, aquades, formalin, media tumbuh (tanah, pasir 1:1). Peralatan yang digunakan antara lain: beaker glass, gelas ukur, pengaduk, plastic ziplock, pipet, penggaris, baki perkecambahan, sprayer, kamera dan alat tulis. Penelitian dilakukan dengan beberapa tahapan meliputi tahap persiapan (media tanam, media simpan dan bahan), pemberian perlakuan (formalin dan periode simpan), tahap penanaman dan perawatan.

Tahap persiapan penelitian dilakukan dengan mempersiapkan media tanam (pasir dan tanah), media simpan (arang sekam) dan bahan penelitian (benih dan formalin). Persiapan media tanam menggunakan pasir dan tanah dengan perbandingan 1 : 1 yang dicampur dan dimasukkan ke baki perkecambahan. Persiapan media simpan dilakukan dengan cara memasukkan arang sekam ke dalam plastik yang telah dilubangi dengan jarum. Persiapan bahan terdiri dari persiapan benih dan formalin. Persiapan benih dilakukan dengan mengupas buah kelengkeng Itoh yang berasal dari satu pohon di Plantera kemudian diambil bijinya lalu dibersihkan dengan air dan dikering anginkan selama semalam. Persiapan formalin dilakukan dengan melakukan perhitungan pengenceran formalin kadar $37 \%$ dengan aquades sehingga diperoleh formalin dengan konsentrasi $0,5 \%, 1 \%$, dan $2 \%$.

Tahap perlakuan formalin dilakukan dengan cara merendam benih yang telah disiapkan pada masing-masing konsentrasi formalin sesuai perlakuan selama 2 jam, kemudian benih ditiriskan dan dilanjutkan dengan tahap perlakuan periode simpan. Tahap perlakuan periode simpan dilakukan dengan memasukkan benih ke dalam plastic ziplock yang telah berisi media simpan, lalu disimpan sesuai perlakuan, kecuali benih dengan tanpa perlakuan penyimpanan (P0) dipisah untuk kemudian dilakukan penanaman.

Tahapan Penanaman dilakukan dengan menanam benih di baki perkecambahan sebanyak 25 benih per baki perkecambahan. Benih ditanam sesuai periode simpan benih yaitu langsung tanam (P0), ditanam setelah 15 hari disimpan (P1) dan setelah 30 hari disimpan (P2).

Tahapan perawatan benih dilakukan setelah benih ditanam di baki perkecambahan dengan melakukan penyiraman tiap pagi dan sore hari selama penelitian berlangsung ( 8 minggu) setelah benih ditanam. Tahapan perawatan dilakukan bersamaan dengan pengamatan parameter benih yang ditanam.Parameter yang diamati meliputi 
daya kecambah, kecepatan berkecambah, jumlah daun dan tinggi bibit.

Penelitian dilaksanakan dengan menggunakan Rancangan Acak Lengkap (RAL) Faktorial. Faktor pertama yaitu konsentrasi formalin dengan 4 taraf, tanpa formalin (F0), formalin $0,5 \%(\mathrm{~F} 1), 1 \%(\mathrm{~F} 2)$ dan $2 \%(\mathrm{~F} 3))$. Faktor kedua adalah periode simpan dengan 3 taraf, tanpa penyimpanan (P0), 15 hari penyimpanan (P1) dan 30 hari penyimpanan (P2). Total terdapat 12 kombinasi perlakuan. Perlakuan diulang sebanyak 4 kali, sehingga mendapatkan 48 unit percobaan dengan 25 benih per unit percobaan. Data yang diperoleh dianalisis ragam taraf 5\% untuk mengetahui pengaruh perlakuan dan apabila perlakuan berpengaruh nyata $(p<0,05)$, dilanjutkan dengan uji jarak berganda Duncan (DMRT) pada taraf 5\% untuk mengetahui perbedaan antar perlakuan.

\section{HASIL DAN PEMBAHASAN}

\section{Daya Kecambah}

Hasil analisis ragam menunjukkan bahwa kadar formalin berpengaruh nyata $(\mathrm{P}<0,05)$, sedangkan lama periode simpan dan interaksi antara kadar formalin dengan lama periode simpan berpengaruh tidak nyata $(\mathrm{P}>0,05)$ terhadap daya kecambah kelengkeng. Hasil uji DMRT daya kecambah kelengkeng tercantum pada Tabel 1 . Tabel 1 menunjukkan bahwa kadar formalin $0 \%$ dan $0,5 \%$ tidak berbeda nyata, namun berbeda nyata dengan kadar formalin $1 \%$ dan $2 \%$. Hal ini menunjukkan bahwa pemberian formalin dengan kadar $1 \%$ atau lebih dapat menurunkan daya kecambah kelengkeng. Penurunan daya kecambah diduga karena formalin bereaksi dengan protein yang ada di dalam benih dan memberikan kerusakan dengan menginaktivasi protein. Cahyadi (2009) menjelaskan bahwa formalin memiliki sifat mudah bereaksi dengan protein, dan protein yang terikat unsur kimia formalin akan diinaktifkan. Hasil pengamatan González-Verdejo dkk, (2005), formalin dapat digunakan sebagai desinfektan pada benih, namun juga memberikan dampak penurunan daya kecambah pada benih Orobanche ramose. Protein yang telah diinaktifkan oleh formalin tidak dapat digunakan secara maksimal oleh benih sebagai sumber makanan di awal perkecambahan benih. Menurunnya daya kecambah benih merupakan dampak dari kerusakan yang terjadi di dalam embrio atau endosperm sehingga metabolisme benih menjadi terhambat (Yudono, 2012).

Tabel 1. Daya kecambah (\%) kelengkeng pada berbagai kombinasi perlakuan formalin dan periode simpan

\begin{tabular}{|c|c|c|c|c|}
\hline \multirow{2}{*}{$\begin{array}{l}\text { Kadar formalin } \\
(\%)\end{array}$} & \multicolumn{3}{|c|}{ Periode Simpan (hari) } & \multirow{2}{*}{ Rata-rata } \\
\hline & 0 & 15 & 30 & \\
\hline 0 & 79,00 & 74,00 & 77,00 & $76,66^{\mathrm{a}}$ \\
\hline 0,5 & 71,00 & 74,00 & 75,00 & $73,33^{\mathrm{a}}$ \\
\hline 1 & 66,00 & 65,00 & 66,00 & $65,66^{\mathrm{b}}$ \\
\hline 2 & 64,00 & 64,00 & 61,00 & $63,00^{\mathrm{b}}$ \\
\hline Rata-rata & 70,00 & 69,25 & 69,75 & \\
\hline
\end{tabular}

Keterangan : Superskrip yang berbeda pada rataan kolom dan baris menunjukkan perbedaan nyata $(\mathrm{P}<0,05)$

\section{Kecepatan Berkecambah}

Hasil analisis ragam menunjukkan bahwa kadar formalin dan lama periode simpan berpengaruh nyata $(\mathrm{P}<0,05)$ terhadap kecepatan berkecambah kelengkeng, sedangkan interaksi antara kadar formalin dengan periode simpan berpengaruh tidak nyata $(\mathrm{P}>0,05)$ terhadap kecepatan berkecambah kelengkeng. Hasil uji
DMRT kecepatan berkecambah kelengkeng tercantum pada Tabel 2 .

Tabel 2 menunjukkan bahwa rata-rata kecepatan berkecambah dengan kadar formalin 0 , $0,5,1$ dan $2 \%$ berturut-turut yaitu 13,31, 12,83, 12,10 dan $11,33 \%$ /hari. Perlakuan tanpa formalin menunjukkan kecepatan berkecambah nyata paling tinggi dan kecepatan berkecambah nyata semakin menurun seiring dengan meningkatnya pemberian 
kadar formalin. Hal ini menunjukkan bahwa dengan meningkatnya pemberian formalin semakin mengganggu proses metabolisme benih untuk berkecambah. Sha-sha et al (2012) menjelaskan bahwa formalin dapat merusak protein. Yudono (2012) menambahkan bahwa protein dalam benih akan dihidrolisis oleh enzim-enzim dalam benih yang penting dalam proses perkecambahan. Tabel 2 menunjukkan bahwa periode simpan dengan 30 hari penyimpanan menunjukkan pengaruh nyata dalam menurunkan kecepatan berkecambah. Hal ini dapat terjadi karena benih kelengkeng termasuk benih rekalsitran yang memiliki daya simpan rendah.
Benih rekalsitran umumnya memiliki kadar air tinggi dan merupakan salah satu faktor yang menyebabkan kemunduran viabilitas dan vigor benih. Kartasapoetra (2003) menjelaskan bahwa semakin tinggi kadar air benih maka kadar $\mathrm{CO}_{2}$ akan meningkat dan kadar $\mathrm{O}_{2}$ akan menurun pada udara disekitar benih karena proses respirasi benih yang meningkat. Sahupala (2010) menambahkan bahwa proses respirasi benih akan terus terjadi selama benih disimpan, maka semakin lama benih disimpan, semakin lama pula benih akan melakukan respirasi dan menyebabkan penurunan mutu fisiologis.

Tabel 2. Kecepatan (\%/hari) berkecambah kelengkeng pada berbagai kombinasi perlakuan formalin dan periode simpan

\begin{tabular}{ccccc}
\hline $\begin{array}{c}\text { Kadar formalin } \\
(\%)\end{array}$ & \multicolumn{3}{c}{ Periode Simpan (hari) } & \multirow{2}{*}{ Rata-rata } \\
\cline { 2 - 4 } & 0 & 15 & 30 & \\
\hline 0 & 13,95 & 13,09 & 12,88 & $13,31^{\mathrm{a}}$ \\
0,5 & 13,04 & 12,90 & 12,52 & $12,83^{\mathrm{b}}$ \\
1 & 12,40 & 12,19 & 11,69 & $12,10^{\mathrm{c}}$ \\
2 & 11,50 & 11,57 & 10,92 & $11,33^{\mathrm{d}}$ \\
Rata-rata & $12,72^{\mathrm{a}}$ & $12,44^{\mathrm{a}}$ & $12,00^{\mathrm{b}}$ & \\
\hline
\end{tabular}

Keterangan : Superskrip yang berbeda pada rataan kolom dan baris menunjukkan perbedaan nyata $(\mathrm{P}<0,05)$

\section{Jumlah Daun}

Hasil analisis ragam menunjukkan bahwa kadar formalin dan interaksi antara kadar formalin dengan periode simpan berpengaruh nyata $(\mathrm{P}<0,05)$ terhadap jumlah daun kelengkeng, sedangkan periode simpan benih kelengkeng tidak berpengaruh nyata $(\mathrm{P}>0,05)$ terhadap jumlah daun kelengkeng. Hasil uji DMRT jumlah daun kelengkeng tercantum pada Tabel 3.

Interaksi yang terjadi pada Tabel 4. menunjukkan bahwa jumlah daun pada perlakuan tanpa formalin dengan 30 hari periode simpan, nyata menurunkan jumlah daun. Kadar formalin 0,5\% dengan 15 hari dan 30 hari penyimpanan, nyata meningkatkan jumlah daun. Kadar formalin $1 \%$ dengan 30 hari periode simpan nyata meningkatkan jumlah daun. Kadar formalin $2 \%$ dengan periode simpan 15 hari nyata meningkatkan jumlah daun, namun pada periode simpan 30 hari nyata menurunkan jumlah daun. Perlakuan tanpa penyimpanan dengan meningkatnya kadar formalin, nyata menurunkan jumlah daun. Periode simpan 15 hari dengan formalin kadar $1 \%$ nyata menurunkan jumlah daun, namun dengan periode simpan yang sama, meningkatnya kadar formalin $2 \%$ nyata meningkatkan jumlah daun. Periode simpan 30 hari dengan kadar formalin 0,5 dan $1 \%$ nyata meningkatkan jumlah daun, namun dengan periode simpan yang sama, kadar formalin $2 \%$ nyata menurunkan jumlah daun. Hasil interaksi pada Tabel 4. menunjukkan bahwa formalin saling mempengaruhi dengan periode simpan. Kombinasi perlakuan formalin $0,5 \%$ dengan periode simpan 30 hari mampu meningkatkan jumlah daun. Hal ini terjadi karena formalin mampu menjadi desinfektan pada benih BPOM (2008) sehingga ketika benih mengalami masa simpan 30 hari, benih terbebas dari serangan penyakit. Benih yang terbebas dari serangan penyakit akan memiliki pertumbuhan yang optimal Sadjad (1999). Peningkatan pertumbuhan daun juga dapat dipengaruhi oleh faktor eksternal tanaman sesuai pendapat Sitompul dan Guritno (1995) bahwa pertumbuhan dan 
perkembangan tanaman bergantung pada fungsi bagian tanaman, daun melakukan fiksasi $\mathrm{CO}_{2}$, akar berfungsi untuk menyerap air dan unsur hara sedangkan batang berfungsi menyalurkan makanan pada seluruh bagian tanaman.

Tabel 3. Jumlah daun kelengkeng pada berbagai kombinasi perlakuan formalin dan periode simpan

\begin{tabular}{ccccc}
\hline $\begin{array}{c}\text { Kadar formalin } \\
(\%)\end{array}$ & \multicolumn{3}{c}{ Periode Simpan (hari) } & \multirow{2}{*}{ Rata-rata } \\
\cline { 2 - 4 } & 0 & 15 & 30 & \\
\hline 0 & $3,75^{\mathrm{a}}$ & $3,50^{\mathrm{ab}}$ & $2,50^{\mathrm{c}}$ & $3,25^{\mathrm{a}}$ \\
0,5 & $3,00^{\mathrm{bc}}$ & $3,75^{\mathrm{a}}$ & $3,25^{\mathrm{ab}}$ & $3,33^{\mathrm{a}}$ \\
1 & $2,25^{\mathrm{d}}$ & $2,25^{\mathrm{d}}$ & $3,25^{\mathrm{abc}}$ & $2,50^{\mathrm{b}}$ \\
2 & $3,00^{\mathrm{bc}}$ & $3,25^{\mathrm{abc}}$ & $3,00^{\mathrm{bcd}}$ & $3,08^{\mathrm{a}}$ \\
Rata-rata & 3,00 & 3,18 & 3,00 &
\end{tabular}

Keterangan : Superskrip yang berbeda pada matriks interaksi menunjukkan perbedaan nyata $(\mathrm{P}<0,05)$

\section{Tinggi Bibit}

Hasil analisis ragam menunjukkan bahwa kadar formalin dan interaksi antara kadar formalin dengan periode simpan berpengaruh nyata $(\mathrm{P}<0,05)$ terhadap tinggi bibit kelengkeng, sedangkan periode simpan benih kelengkeng tidak berpengaruh nyata $(\mathrm{P}>0,05)$ terhadap tinggi bibit kelengkeng. Hasil uji DMRT tinggi bibit kelengkeng tercantum pada Tabel 4.

Interaksi yang terjadi pada Tabel 4. menunjukkan bahwa perlakuan tanpa formalin periode simpan 30 hari, nyata menurunkan tinggi bibit kelengkeng. Kadar formalin $0,5 \%$ dengan periode simpan 15 dan 30 hari nyata meningkatkan tinggi bibit kelengkeng. Kadar formalin 1\% dengan periode simpan 30 hari nyata meningkatkan tinggi bibit kelengkeng. Kadar formalin 2\% dengan tanpa penyimpanan nyata paling tinggi meningkatkan tinggi bibit kelengkeng. Perlakuan tanpa penyimpanan dengan formalin $2 \%$ nyata paling tinggi meningkatkan tinggi bibit kelengkeng. Periode simpan 15 hari dengan formalin $1 \%$ nyata menurunkan tinggi bibit kelengkeng, namun kadar formalin $2 \%$ nyata meningkatkan tinggi bibit kelengkeng. Periode simpan 30 hari dengan kadar formalin $0,5,1$ dan $2 \%$ nyata meningkatkan tinggi bibit kelengkeng.

Tabel 4. Tinggi bibit $(\mathrm{cm})$ pada berbagai kombinasi perlakuan formalin dan periode simpan

\begin{tabular}{ccccc}
\hline Kadar formalin & \multicolumn{3}{c}{ Periode Simpan (hari) } & \multirow{2}{*}{ Rata-rata } \\
\cline { 2 - 4 }$(\%)$ & 0 & 15 & 30 & \\
\hline 0 & $8,05^{\mathrm{b}}$ & $7,75^{\mathrm{b}}$ & $5,88^{\mathrm{def}}$ & $7,23^{\mathrm{a}}$ \\
0,5 & $6,26^{\mathrm{cde}}$ & $8,35^{\mathrm{b}}$ & $7,66^{\mathrm{bc}}$ & $7,43^{\mathrm{a}}$ \\
1 & $5,41^{\mathrm{ef}}$ & $5,16^{\mathrm{f}}$ & $7,14^{\mathrm{bc}}$ & $5,91^{\mathrm{b}}$ \\
2 & $9,84^{\mathrm{a}}$ & $6,95^{\mathrm{bcd}}$ & $7,08^{\mathrm{bcd}}$ & $7,96^{\mathrm{a}}$ \\
Rata-rata & 7,39 & 7,05 & 6,94 & \\
\hline
\end{tabular}

Keterangan : Superskrip berbeda pada matriks interaksi menunjukkan perbedaan nyata $(\mathrm{P}<0,05)$.

Hasil interaksi pada Tabel 4. berbeda dengan pernyataan Sha-sha dkk (2012) bahwa paparan formalin menurunkan pertumbuhan tanaman. Hal itu dapat terjadi karena perbedaan kadar formalin yang diberikan pada tanaman. Adanya interaksi menunjukkan bahwa formalin saling mempengaruhi dengan periode simpan. Benih yang diberi perlakuan formalin akan bebas dari serangan cendawan karena formalin dapat menjadi desinfektan sebagaimana dijelaskan oleh BPOM (2008). Benih yang bebas dari serangan cendawan selama masa simpan akan memiliki pertumbuhan yang optimum, Sadjad (1999). Sitompul dan Guritno (1995) menyampaikan bahwa ada faktor 
eksternal yang mempengaruhi pertumbuhan, diantaranya yaitu tanaman yang telah berkecambah tumbuh dan berkembang bergantung pada fungsi bagian tanaman tersebut, daun melakukan fiksasi $\mathrm{CO}_{2}$, akar berfungsi untuk menyerap air dan unsur hara sedangkan batang berfungsi menyalurkan makanan pada seluruh bagian tanaman.

\section{KESIMPULAN}

Berdasarkan hasil penelitian disimpulkan bahwa pemberian formalin 1 dan $2 \%$ menurunkan daya kecambah benih kelengkeng. Meningkatnya pemberian formalin dan periode simpan 30 hari menurunkan kecepatan berkecambah benih kelengkeng. Perlakuan tanpa formalin dengan periode simpan 15 hari dapat meningkatkan jumlah daun, jika kadar formalin ditingkatkan ke 0,5\% dengan 30 hari periode simpan juga mampu meningkatkan jumlah daun. Formalin $2 \%$ tanpa periode simpan dapat meningkatkan tinggi bibit kelengkeng, sedangkan perlakuan dengan 15 dan 30 hari periode simpan tanpa pemberian formalin dan formalin $0,5 \%$ meningkatkan tinggi bibit kelengkeng.

\section{DAFTAR PUSTAKA}

Balitjestro. 2014. Perbanyakan Tanaman Lengkeng dengan Biji. [Diakses tanggal 14 Maret 2017].

http://balitjestro.litbang.pertanian.go.id/per banyakan-tanaman-lengkeng-dengan-biji/.

BPOM.2008. Formalin (Larutan Formaldehid). Jakarta. Direktorat Pengawasan Produk dan Bahan Berbahaya Badan Pengawas Obat dan Makanan RI.

Cahyadi, W. 2009. Analisis dan Aspek Kesehatan: Bahan Tambahan Pangan. Edisi ke-2. Jakarta (ID): Bumi Aksara.

González V., C. I., X. Barandiaran L., M. T. Moreno Y., J. I. Cubero S., dan A. D. Pietro. 2005. An improved axenic system for studying pre-infection development of the parasitic plant Orobanche ramosa. Annals Bot. 96: 1121-1127.
Kartasapoetra A.G. 2003. Teknologi Benih : Pengolahan Benih dan Tuntunan Praktikum. Rineka Cipta. Jakarta.

Rukmana, Rahmat. 2005 Lengkeng, Prospek Agrobisnis Dan Teknik Budi Daya. Kanisius. Yogyakarta.

Sadjad, S., E. Murniati, dan S. Ilyas. 1999. Parameter Pengujian Vigor Benih Dari Komparatif Ke Simulatif. Jakarta. PT Grasindo.

Sahupala, A. 2010. Pengaruh Suhu dan Lama Penyimpanan Terhadap Viabilitas Benih Merbau (Intsia bijuga, OK). Jurnal Agroforestri. V (4): 265-271.

Sha-Sha, W., Z. Bang, S. Z. Sun. J. Zhang. Y. Mei. H. Juan, N. K. Zhi Li. L. M. Chen. 2012. Physiological and transcriptional analysus of effect of formaldehyde exposure on Arabidopsis thaliana. Acta Physiol Plant 2012 (34) : 923-936

Sitompul, S. M., B. Guritno. 1995. Analisis Pertumbuhan Tanaman. Yogyakarta. Gadjah Mada University Press.

Sutopo, L. 2012. Teknologi Benih. Jakarta. PT Raja Grafindo Persada.

Yudono, P.2012. Perbenihan Tanaman Dasar Ilmu, Teknologi Dan Pengelolaan. Yogyakarta.Gadjah Mada University Press.Agustina L. 2004. Dasar Nutrisi Tanaman. PT Rineka Cipta, Jakarta 